\title{
The number of PON1 mutant alleles, but not PON1 phenotype, is associated with Gensini score of coronary damage
}

\section{Numărul alelelor mutante ale PON1, dar nu şi fenotipul PON1, este asociat cu scorul Gensini de afectare coronariană}

\author{
Irina Ilea ${ }^{1}$, Iulia Lupan ${ }^{2}$, Daniel Corneliu Leucuta ${ }^{3}$, Caius Romulus Duncea ${ }^{1}$, \\ Maria Dronca $^{4 *}$ \\ 1. Department of Cardiology, $5^{\text {th }}$ Medical Clinic, Iuliu Hațieganu University of Medicine and \\ Pharmacy Cluj-Napoca, Romania \\ 2. Molecular Biology Center, Institute for Interdisciplinary Research in Bio-Nano-Science, \\ Babeş-Bolyai University Cluj-Napoca, Romania \\ 3. Department of Medical Informatics and Biostatistics, Iuliu Hațieganu University of Medicine and Pharmacy \\ 4. Department of Medical Biochemistry, Iuliu Hațieganu University of Medicine and Pharmacy \\ Cluj-Napoca, Romania
}

\begin{abstract}
Objectives. The aim of this study was to examine the effects of single nucleotide polymorphisms (SNPs) of PON1 gene at the level of promoter region (-909 and -832$)$ and of first exon $(+575$, A20352G, resulting Q192R substitution) on paraoxonase-1 (PON1) activities in 53 patients with angiographycally proven coronary heart disease (CHD) and 17 free-CHD subjects. Methods and Results. Serum PON1 arylesterase (Ar-ase) and salt-stimulated paraoxonase (ssPO-ase) activities were assessed with manual spectrophotometric methods, by using phenyl acetate and paraoxon as substrates. Common serum biochemical markers were assayed by enzymatic methods using commercial kits, on a Roche/Hitachi 912 Auto Analyzer. PON1 genotypes were determined by PCR and nucleotide sequencing of the amplicons with an ABI PRISMTM 310 Genetic Analyzer and a BigDye ${ }^{\circledR}$ Terminator v3.1 Cycle Sequencing Kit. The severity of coronary artery stenosis was assessed and classified using the Gensini score. We found no significant differences in the PON1 activities and $-909(G \rightarrow C),-832(G \rightarrow A)$ and $+575(A \rightarrow G)$ PON1 polymorphisms between CHD and CHD-free groups. Considering all investigated subjects, we found that $-909(G \rightarrow C)$ and $+575(A \rightarrow G)$ SNPs had statistically significant effects on Ar-ase activity and $P O$-ase activity, respectively. In a multiple regression model we found that diabetes, LDL-cholesterol and the number of mutant alleles were significant independent determinants of the Gensini score. A significant positive correlation was observed only between the Gensini score and the number of mutant alleles. Conclusions. There are no differences between CHD and CHD-free groups regarding PON1 genotypes and phenotypes but the increasing number of PON1 mutant alleles is an important factor in determining the severity of coronary damage.
\end{abstract}

Keywords: paraoxonase-1; arylesterase; atherosclerosis; Gensini score; genotyping

*Corresponding author: Maria Dronca PhD, Associate Professor, Department of Medical Biochemistry, „Iuliu Haţieganu" University of Medicine and Pharmacy, 6 Pasteur Street, 400349 Cluj-Napoca, Romania Tel.: + 40-745-023201, Fax: +40-264-597257, E-mail: m_dronca@yahoo.com 


\section{Rezumat}

Obiective. Scopul acestui studiu a fost de a examina efectele polimorfismelor (SNPs) genei PON1 la nivelul regiunii promotor $(-909$ şi -832$)$ şi a primului exon $(+575,20352 A>G$, rezultând substituirea Q192R) asupra activităților paraoxonazei-1 (PON1) într-un grup format din 53 de pacienți cu boală coronariană (CHD) dovedită angiografic şi 17 subiecți fără CHD. Metode şi rezultate. Activitățile PON1 din ser, respectiv arilesteraza (AR-ase) şi paraoxonaza NaCl-stimulată (ssPO-ase), au fost evaluate cu metode spectrofotometrice manuale, folosind acetat de fenil, respectiv paraoxon ca substrat. Markerii biochimici uzuali au fost analizați prin metode enzimatice, pe analizorul Roche/Hitachi 912, folosind kituri comerciale. Genotipurile PON1 au fost determinate folosind PCR, iar pentru secvențierea ampliconilor s-a utilizat kitul BigDye ${ }^{\circledR}$ Terminator v3.1 şi analizorul ABI PRISM ${ }^{T M}$ 310. Severitatea stenozei coronariane s-a evaluat şi clasificat folosind scorul Gensini. $\mathrm{Nu}$ s-au observat diferențe semnificative statistic între grupurile cu şi fără CHD în ceea ce priveste activitățile PON1 şi polimorfismele $-909 G>C,-832 G>A$ şi $+575 A>G$. Dar, luând în considerare toți subiecții investigați, am constatat că SNPs $-909 G>C$ şi $+575 A>G$ au avut efecte semnificative statistic asupra AR-ase, respectiv $P O$-ase. Folosind modelul regresiei multiple am constatat că diabetul, LDL-colesterolul şi numărul de alele mutante au fost determinanți semnificativi, independenți, ai scorului Gensini. O corelație pozitivă semnificativă a fost observată numai între scorul Gensini şi numărul de alele mutante. Concluzii. Nu există diferențe între subiecți cu si fără CHD în ceea ce priveşte genotipurile şi fenotipurile PON1, dar creşterea numărului de alele PON1 mutante este un factor important în determinarea severității leziunilor coronariene.

Cuvinte-cheie: paraoxonaza 1, arilesteraza, ateroscleroza, scorul Gensini, genotipare.

Received: $5^{\text {th }}$ August 2013; Accepted: $16^{\text {th }}$ November 2013; Published: $9^{\text {th }}$ December 2013.

\section{Introduction}

Paraoxonase 1 (PON1) is considered to have the major role in the antiatherogenic activity of HDL (1). From a functional perspective, PON1 displays several activities. It can act as a phosphotriesterase (better known as paraoxonase), arylesterase, lactonase, peroxidase and $\mathrm{A}_{2}$-like phospholipase (2).

To a considerable degree, PON1 level and/or catalytic efficiency are determined by genetic variants (single nucleotide polymorphisms: SNPs) in the regulatory and coding regions. PON1 serum concentration and the traditional assayed activities (paraoxonase and arylesterase) are mostly influenced by promoter polymorphisms $-909 \mathrm{G} \rightarrow \mathrm{C},-162 \mathrm{~A} \rightarrow \mathrm{G}$ and $-108 \mathrm{C} \rightarrow \mathrm{T}$ and exonic polymorphisms $11714 \mathrm{~T} \rightarrow \mathrm{A}$ and $20352 \mathrm{~A} \rightarrow \mathrm{G}$, resulting in a $\operatorname{Leu}(\mathrm{L}) / \mathrm{Met}(\mathrm{M})$ and $\mathrm{Gln}(\mathrm{Q}) / \operatorname{Arg}(\mathrm{R})$ substitutions at codons 55 and $192(+575$, nucleotide position), respectively $(3 ; 4)$.

Contradictory results have been reported regarding $P O N 1$ polymorphisms, paraox- onase (PO-ase) and arylesterase (AR-ase) activities in the coronary heart disease (CHD) (5).

The aim of this study was to examine the effects of three PON1 gene SNPs in the promoter region (-909 and -832) and first exon $(+575,20352 \mathrm{~A} \rightarrow \mathrm{G}$, resulting Q192R substitution) on salt-stimulated paraoxonase (ssPO-ase) and AR-ase activities, and also the distribution of these SNPs in a group with angiographycally proven coronary heart disease (CHD) and freeCHD subjects, addressing the question of whether PON1 genotypes and/or phenotypes are important in determining the severity of coronary atherosclerosis assessed and classified using the Gensini score.

\section{Materials and methods}

\section{Subjects}

The study populations consisted of 70 subjects (53 with CHD and 17 CHD-free) originating from Transylvania (Romania) who presented, between November 2008 and March 
2009, at the Cardiology Department of Heart Institute "Niculae Stăncioiu" Cluj-Napoca, for coronary angiography (because of symptoms related to ischemic heart disease). Each angiogram was reviewed by two interventional cardiologists who had no access to clinical and biochemical measurements of the investigated subjects. The degree of stenosis was defined as the largest percentage of luminal diameter narrowing of the vessel, reported to the nearest segment that was considered normal as measured using specialized QCA software (Quantificative Coronary Angiography, Sanders Data Systems, LLC Palo Alto, California, USA). The severity of coronary artery stenosis was assessed and classified using the Gensini Score $(\mathrm{GS}=n \times N)(6)$, which allows severity scoring of each major epicardial coronary artery, depending on luminal stenosis degree and topographic importance of the question artery in myocardial vasculature. Luminal diameter reduction was assessed and to each reduction percentage $(25 \%, 50 \%, 75 \%, 90 \%, 99 \%$ and $100 \%)$ a specific initial score (n) was attributed $(1,2,4,8,16$, and 32 , respectively). Each vascular segment was then credited with a number (N) multiplied by $n$. The value of $N$ is given in accordance with the functional importance of myocardial area served by the vascular segment, as follows: 5 for the left main trunk (LM), 2.5 for the proximal left anterior descending artery (LAD) and for the proximal circumflex artery (CX), 1.5 for the medium segment of LAD, 1 for the right coronary artery (CD), distal segment of LAD, medium and distal circumflex artery, diagonal artery (D1), the first obtuse marginal artery (OM1), and posterior interventricular artery (PIV) and 0.5 for other branches.

All subjects included in the study were evaluated by physical examination and a detailed questionnaire, concerning known CHD risk factors, cardiac history, and current medications. Weight and height were determined using the standard scale, and body mass index (BMI) was calculated by the formula: BMI $\left(\mathrm{kg} / \mathrm{m}^{2}\right)=$ weight/height ${ }^{2}$.

Patients older than 68 years, with associated neoplastic disease, other cardiomyopathies, chronic inflammatory diseases, liver and kidney diseases, major depression disorder personality, or history of surgical procedures performed in the last 30 days were excluded the study. For all performed measurements, patients' written consent and Ethics Committee approval were obtained.

\section{Blood samples}

Two venous blood samples were collected from each patient (before coronary angiography, after overnight fasting) on clot-activator and on EDTA, respectively. The serum, isolated by low speed centrifugation, was divided into 2 aliquots and stored at $-20^{\circ} \mathrm{C}$ for common biochemical measurements and paraoxonase activities assay.

Common serum biochemical measurements

Total cholesterol (TC), triglycerides (TGs), HDL-cholesterol (HDL-C) and glucose, expressed in $\mathrm{mg} / \mathrm{dl}$, were assayed by enzymatic methods using commercial kits, on a Roche/Hitachi 912 Auto Analyzer.

LDL-cholesterol (LDL-C), expressed in $\mathrm{mg} / \mathrm{dl}$, was calculated using the Friedewald formula (LDL-C = TC - HDL-C - TG/5).

\section{Analysis of serum PON1 activities}

Salt stimulated paraoxonase (ssPO-ase) and arylesterase activities (AR-ase) were measured spectrophotometrically at $25^{\circ} \mathrm{C}$, on a double beam UV-VIS spectrophotometer (ABLE\&JASCO) with Peltier cooled cell holder with stirrer, according to Eckerson et al. (7) with minor modifications.

SsPO-ase activity was performed by using paraoxon (O,O-diethyl-O-p-nitrophenyl phosphate; Sigma Chemical Co., UK) as substrate. The assay mixture contained $1.0 \mathrm{mM}$ paraoxon, $2 \mathrm{M} \mathrm{NaCl}$ and $1 \mathrm{mM} \mathrm{CaCl} 2$ in $50 \mathrm{mM}$ glycine- $\mathrm{NaOH}$ buffer ( $\mathrm{pH}$ 10.5). The reaction was started by the addition of the serum sample and the absorbance was monitored at $405 \mathrm{~nm}$ for 90 seconds. 
AR-ase activity was measured using $1 \mathrm{mM}$ phenyl acetate (Sigma Chemical Co.) in $20 \mathrm{mM}$ Tris- $\mathrm{HCl}(\mathrm{pH}$ ) containing $1 \mathrm{mM}$ $\mathrm{CaCl}_{2}$. The rate of phenyl acetate hydrolysis was determined by monitoring the increase of absorbance at $270 \mathrm{~nm}$ over a 90 -seconds period.

A blank sample, containing incubation mixture without serum, was run simultaneously to correct for spontaneous substrate breakdown, for both activity determinations. All samples were run in duplicate; the average value was used for activity calculation using a molar extinction coefficient of $18.290 \mathrm{M}^{-1} \mathrm{~cm}^{-1}$ at $412 \mathrm{~nm}$ for $p$-nitrophenol, and $1,310 \mathrm{M}^{-1} \mathrm{~cm}^{-1}$ at $270 \mathrm{~nm}$ for phenol. Results were expressed as $\mathrm{U} / \mathrm{L}$ for ssPO-ase activity and as $\mathrm{kU} / \mathrm{L}$ for AR-ase activity.

\section{DNA Extraction and Genotyping}

The whole blood (collected on EDTA) was used for genomic DNA extraction using a Wizard®Genomic DNA Purification Kit (Promega). The amplicons corresponding to PON1 gene promoter SNPs (-909 and -832$)$ and Q192R in the PON1 protein (respectively +575 in the PON1 mRNA) were obtained by PCR. The following primers were designed at the Molecular Biology Center according to sequences from NCBI database: - FW primer: 5'-AGGACAGATATTGCAGAAGAG-3' and RV primer: 5'GATTCAGTAGCTTGATCATGG-3', for SNPs -909 and -832

- FW primer: 5'-CTTTAAGGATTGTATCGGCAG-3', and RV primer: 5'-CAAATCTTCATCACAGTTCCC-3', for SNP +575 (Q192R).

The nucleotide sequencing of the amplicons was performed with an ABI PRISM ${ }^{\mathrm{TM}}$ 310 Genetic Analyzer (Applied Biosystems) using the BigDye ${ }^{\circledR}$ Terminator v3.1 Cycle Sequencing Kit (Applied Biosystems).

\section{Statistical analysis}

Qualitative data was presented as counts and percentages. The association between qualitative variables was assessed with $\chi^{2}$ test (if the expected frequencies table had more than $80 \%$ of the cells with values greater than five) or Fisher exact test otherwise.
Quantitative data was presented by mean and standard deviation (for normally distributed data), and by median and interquartile range for not normally distributed data. To check for differences between two independent groups of quantitative data, Mann Whitney $U$ test was used (for not normally distributed data). Normality of the data was checked with strip-chart, quantile-quantile plot, and ShapiroWilk test. Comparisons between three of more groups regarding quantitative variables were made with the Kruskal Wallis test for not normally distributed data.

Association between quantitative data was evaluated first graphically with a scatter chart, then using Spearman correlation coefficient (for data not following the normal distribution) with $95 \%$ confidence intervals (calculated by bootstrapping), along with the test for its statistical significance. For some of the variables, simple and multiple linear regression, was performed. The regression assumptions (normality of residuals, heteroscedasticity and so on) were checked and the regression coefficients with 95\% confidence intervals were presented.

For all statistical tests used, the significance level alpha was 0.05 , and the two-tailed $p$ value was computed. The statistical analysis was made in $\mathrm{R}$ environment for statistical computing and graphics, version 1.15. (8).

\section{Results}

Demographic data as well as clinical and laboratory findings in CHD and CHD-free patients are presented in Table 1. The statistical analysis of the groups did not show significant difference regarding age, gender distribution, and incidence of coronary risk factors such as hypertension, smoking, body mass index. There was a significant difference between CHD and CHD-free groups concerning the presence of diabetes or impaired glucose tolerance (IGT). In the CHD group there were $35.85 \%$ subjects with IGT and $32.08 \%$ patients with type II diabetes, 
Table 1. Demographic as well as clinical and laboratory data of the investigated subjects

\begin{tabular}{|c|c|c|c|}
\hline Characteristics & CHD $(n=53)$ & CHD-free $(n=17)$ & $p$ \\
\hline *Age, $\mathrm{y}$ & $53[47-56]$ & $55[50-57]$ & 0.597 \\
\hline Men, n (\%) & $42(79.25)$ & $13(76.47)$ & 1 \\
\hline$* \mathrm{BMI}, \mathrm{kg} / \mathrm{m}^{2}$ & $28.3[26-31.29]$ & $27.9[25.6-30.69]$ & 0.886 \\
\hline Hypertension, n (\%) & $30(56.6)$ & $9(52.94)$ & 0.791 \\
\hline Smoking, n (\%) & $29(54.72)$ & $5(29.41)$ & 0.069 \\
\hline \multirow[t]{3}{*}{ Diabetes, n (\%) } & $\mathrm{IT}=7(13.21)$ & $\mathrm{IT}=0(0)$ & \\
\hline & $\mathrm{OAT}=10(18.87)$ & $\mathrm{OAT}=0(0)$ & 0.018 \\
\hline & $\mathrm{NT}=36(67.92)$ & $\mathrm{IGT}=17(100)$ & \\
\hline Acute coronary syndrome, $\mathrm{n}(\%)$ & $20(37.74 \%)$ & $1(5.88 \%)$ & 0.012 \\
\hline Previous MI, n (\%) & $21(39.62 \%)$ & $0(0 \%)$ & 0.009 \\
\hline Statines therapy, n $(\%)$ & $28(52.83)$ & $8(47.06)$ & 0.678 \\
\hline *Total cholesterol mg/dL & 173 [153-192] & $143[132-180]$ & 0.013 \\
\hline *HDL-cholesterol mg/dL & $34.2[31.2-39.4]$ & $36.1[30-44.4]$ & 0.962 \\
\hline *LDL-cholesterol mg/dL & $130.6[106.8-152]$ & $105[84.8-132.4]$ & 0.022 \\
\hline *Triglyceride $\mathrm{mg} / \mathrm{dL}$ & $152[110-200]$ & $152[123-200]$ & 0.913 \\
\hline$*$ AR-ase, $\mathrm{kU} / \mathrm{L}$ & $72.5[60.62-79.06]$ & $68.76[58.76-85.02]$ & 0.935 \\
\hline *PO-ase, U/L & $250.4[157.9-437.3]$ & $312.5[196-418.4]$ & 0.481 \\
\hline \multicolumn{4}{|l|}{$-909 \mathrm{G}>\mathrm{C}$} \\
\hline GG, n (\%) & $12(22.64)$ & $5(29.41)$ & \multirow{3}{*}{0.826} \\
\hline $\mathrm{GC}, \mathrm{n}(\%)$ & $26(49.06)$ & $7(41.18)$ & \\
\hline $\mathrm{CC}, \mathrm{n}(\%)$ & $15(28.30)$ & $5(29.41)$ & \\
\hline \multicolumn{4}{|l|}{$-832 G>A$} \\
\hline $\mathrm{GG}, \mathrm{n}(\%)$ & $24(45.28)$ & $11(64.71)$ & \multirow{3}{*}{0.368} \\
\hline $\mathrm{GA}, \mathrm{n}(\%)$ & $26(49.06)$ & $6(35.29)$ & \\
\hline $\mathrm{AA}, \mathrm{n}(\%)$ & $3(5.66)$ & $0(0)$ & \\
\hline \multicolumn{4}{|l|}{$+575 \mathrm{~A}>\mathrm{G} / \mathrm{Q} 192 \mathrm{R}$} \\
\hline $\mathrm{AA} \rightarrow \mathrm{QQ}, \mathrm{n}(\%)$ & $26(49.06)$ & $8(47.06)$ & \multirow{3}{*}{0.691} \\
\hline $\mathrm{AG} \rightarrow \mathrm{QR}, \mathrm{n}(\%)$ & $24(45.28)$ & $7(41.18)$ & \\
\hline $\mathrm{GG} \rightarrow \mathrm{RR}, \mathrm{n}(\%)$ & $3(5.66)$ & $2(11.76)$ & \\
\hline
\end{tabular}

$\mathrm{IT}=$ insulin therapy; OAT $=$ oral antihyperglycemic therapy; NT $=$ no therapy.

*For non-normal distribution, data are presented as median [lower/upper quartiles]

while in the CHD-free group there were only $29.41 \%$ with IGT and no diabetics. Higher values of LDL-cholesterol and total cholesterol were observed in the CHD group compared to CAD-free group. No significant differences between investigated groups regarding PON1 activities and the distribution of analyzed genotypes $(-909 \mathrm{G} \rightarrow \mathrm{C},-832 \mathrm{G} \rightarrow \mathrm{A}$ and $+575 \mathrm{~A} \rightarrow \mathrm{G})$ were observed. Considering all investigated subjects, we found that $-832 \mathrm{G} \rightarrow \mathrm{A}$ SNP had no effects on PON1 activities, but $-909 \mathrm{G} \rightarrow \mathrm{C}$ and $+575 \mathrm{~A} \rightarrow \mathrm{G}$ SNPs had very significant effects on
AR-ase activity and ssPO-ase activity, respectively (Table 2). In the investigated population we identified patients without mutant alleles $(n=3)$ with one $(n=13)$, two $(n=29)$, three $(n=19)$ and four mutant alleles $(n=6)$. We did not identify patients with five or six mutant alleles. The mean values of Gensini score fluctuates between 14 (for subjects without mutant alleles) and 71 (for subjects with four mutant alleles). A significant positive correlation was observed between the Gensini score and the number of mutant alleles (Figure 1). In a multiple regression model, includ- 
Table 2. PO-ase and AR-ase activities related to investigated genotypes

\begin{tabular}{lccc}
\hline & $\mathbf{- 9 0 9 G}>\mathbf{C}$ & $\mathbf{- 8 3 2 G}>\mathbf{A}$ & $\mathbf{+ 5 7 5 A}>\mathbf{G}$ \\
\hline AR-ase (kU/L) & GG 80.04 [74.94-83.09] & GG 65.32[55.68-78.93] & AA 75.26 [64.04-82.99] \\
& GC 72.65[63.03-79.31] & GA 73.57 [64.01-79.53] & AG 68.47 [58.48-75.43] \\
& CC 58.47[48.98-65.37] & AA 80.04 [75.92-81.37] & GG 63.03 [58.76-74.67] \\
& $p<0.001$ & $p=0.113$ & $p=0.181$ \\
ssPO-ase (U/L) & GG 197.1[179.4-391.5] & GG 196[138.8-402.35] & AA 161.85[126.33-189.75] \\
& GC 386.3[161-480.6] & GA 359.55[179.3-493.9] & AG 400.1 [316.85-494.1] \\
& CC 263.05[122.95-357.22] & AA 197.1[173.25-370.45] & GG 679.6 [669-915.2] \\
& $p=0.299$ & $p=0.175$ & $p=0.001$ \\
\hline
\end{tabular}

Table 3. Predictors of Gensini score identified by logistic regression

\begin{tabular}{lccc}
\hline Variable & $\boldsymbol{\beta}$ & $\mathbf{9 5 \%} \mathbf{C I}$ & $\boldsymbol{p}$ \\
\hline Arylesterase activity $(\mathrm{kU} / \mathrm{L})$ & -0.14 & $(-0.85-0.58)$ & 0.705 \\
BMI $\left(\mathrm{kg} / \mathrm{m}^{2}\right)$ & 0.74 & $(-1.47-2.95)$ & 0.504 \\
Diabetes mellitus & 29.24 & $(6.86-51.63)$ & 0.011 \\
Smoker status & 5.78 & $(-15.68-27.25)$ & 0.592 \\
Gender & 14.44 & $(-10.12-39)$ & 0.244 \\
HDL-cholesterol (mg/dL) & -0.08 & $(-1.13-0.97)$ & 0.881 \\
Hypertension & -4.15 & $(-25.06-16.75)$ & 0.692 \\
LDL-cholesterol $(\mathrm{mg} / \mathrm{dL})$ & 0.28 & $(0.05-0.52)$ & 0.018 \\
Number of mutant alleles & 13.53 & $(1.61-25.44)$ & 0.027 \\
Paraoxonase activity (U/L) & -0.02 & $(-0.08-0.03)$ & 0.393 \\
Triglycerides (mg/dL) & -0.01 & $(-0.08-0.08)$ & 0.982 \\
Age (years) & 0.27 & $(-1.2-1.74)$ & 0.717 \\
\hline
\end{tabular}

$\beta$ is standardized regression coefficient. $\mathrm{CI}$ is confidence interval

ing 12 explanatory variables for the Gensini score as a dependent parameter, we found that diabetes, LDL-cholesterol and the number of mutant alleles were significant independent determinants (Table 3). Age, smoking, hypertension, total cholesterol, HDL-cholesterol, triglycerides, and PON1 activities did not appear to be related to the Gensini score. The gender influence was close to the limit of significance.

\section{Discussion}

In the present study we examined three PON1 gene SNPs: two located in the promoter re- gion (-832 and -909) and one in the coding region $(+575)$. Earlier reports $(9 ; 10)$ have shown a significant effect of the PON1 -108 and -909 promoter region SNPs of both PON1 activities. Recently, the results of Mackness et al. (11), using paraoxon as a substrate, validate the effect of the -108 SNP on PON1 activity in control group (CHD-free) as well as in the CHD group, on one hand, and the effect of the -909 SNP on PON1 activity only in the CHD group, on the other hand. Also, both -108 and -909 SNPs were not related to the presence of CHD. In this paper, by evaluating the PON1 activities and the distributions of two SNPs in the promoter region in each investi- 


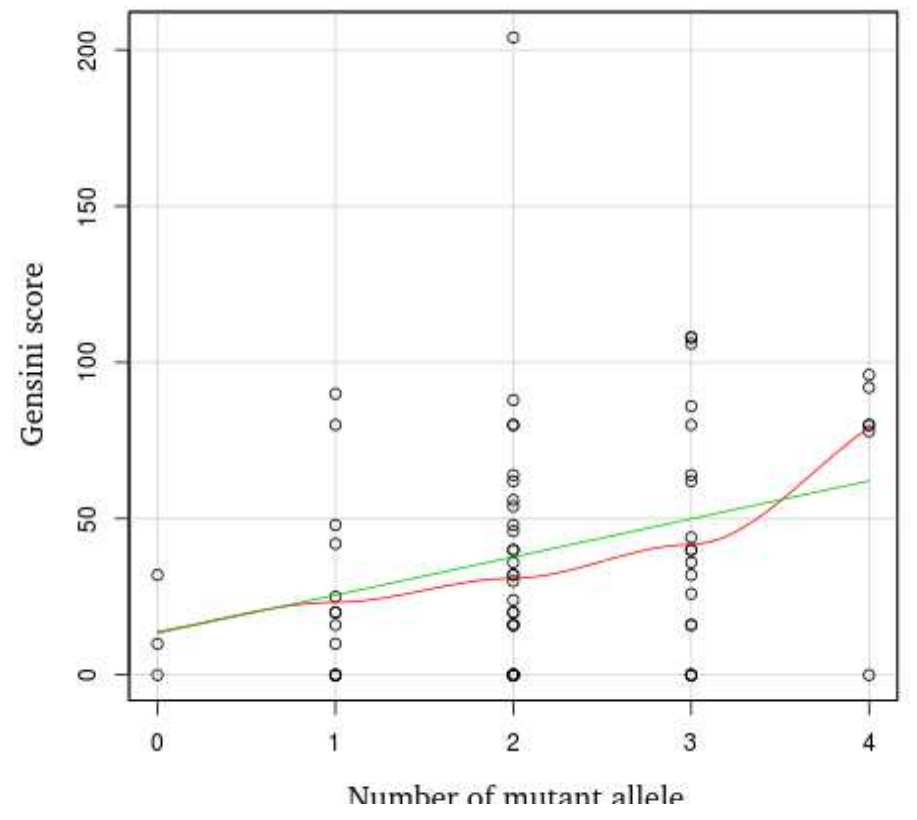

Figure 1. Positive correlation between the number of mutant alleles and Gensini score.

gated groups we obtained no significant differences. However, considering all investigated subjects we found that the PON1 $-832 \mathrm{G} \rightarrow \mathrm{A}$ indeed had no effect on PON1 activities, but $-909 \mathrm{G} \rightarrow \mathrm{C}$ had statistically significant effect on AR-ase activity (using phenyl acetate as a substrate), and $+575 \mathrm{~A} \rightarrow \mathrm{G}$ (resulting a Q192R substitution at the protein level) on ssPO-ase activity (using paraoxon as a substrate). The causes of these differences are still ambiguous. Discrepancies in the results described here and those of other investigators could be due to distinct methodologies used between studies. Furlong, in his paper (12), pointed out that the differences in PON1 activity, concentration and genotype distribution occur between different world populations. Previously, Wheeler et al. (13) in a meta-analysis of 43 studies, showed a small but significantly odds ratio for the association of PON1-192R allele and CHD. For that reason, differences between populations from different geographical areas may be the main cause for any difference between our study and other reports. It is also expected that the PON1 SNPs only have a mi- nor impact on CHD progression, which may be overawed by competing effects of dietary and environmental factors affecting CHD and PON1 activity in some populations more than in others (11). Remarkably is that our study shows a positive correlation between Gensini score and the number of mutant alleles. Also, a multiple regression model including 12 explanatory variables for the Gensini score as a dependent parameter indicates that diabetes, LDL-cholesterol and the number of mutant alleles are meaningful independent determinants.

In conclusion, regarding the PON1 genotypes and phenotypes, there are no significant differences between CHD and CHD-free groups, but the increasing number of PONI mutant alleles is an important factor controlling the severity of coronary damage. More large prospective studies will better clarify the correlations between PONI SNPs and CHD in the future.

\section{Acknowledgements}

The authors are grateful to the staff of the Cardiology Department of the Heart Institute "Niculae Stăncioiu" Cluj-Napoca, especially to Dr. Ştefan Moț, for their expert technical assistance and assessment of all angiographic images.

\section{References}

1. Mackness B, Durrington PN, Mackness MI. The paraoxonase gene family and coronary heart disease. Curr Opinion Lipidol 2002; 13: 357-62.

2. Draganov, D. I., and B. N. La DuPharmacogenetics of paraoxonases: a brief review. Naunyn Schmiedebergs Arch Pharmacol 2004; 369: 78-88.

3. Furlong CE, Richter RJ, Li WF, Brophy VH, Carlson C, Rieder M, Nickerson D, Costa LG, Ranchalis J, Lusis AJ, Shih DM, Tward A, Jarvik GP., The functional consequences of polymorphisms in the PON1 gene. In: The Paraoxonase: Their Role in Disease Development and Xenobiotic Metabolism. Mackness B, Mackness M, Aviram $M$ and Paragh G. (eds.) Springer, Dordrecht, 
Netherlands: 2008; Chapter 17, 267-281

4. Roest, M., T. M. van Himbergen, A. B. Barendrecht, P. H. Peeters, Y. T. van der Schouw, and H. A. Voorbij.. Genetic and environmental determinants of the PON-1 phenotype. Eur J Clin Invest 2007; 37: 187-196.

5. Mackness M, Mackness B. Paraoxonase 1 and atherosclerosis: Is the gene or the protein more important? Free Radic Bio Med 2004; 37(9): 1317-23

6. Gensini GG. A more meaningful scoring system for determining the severity of coronary heart disease. Am J Cardiol 1983; 51(3): 606.

7. Eckerson HW, Wyte CM, La Du BN. The human serum paraoxonase/arylesterase polymorphism. Am J Hum Genet 1983; 35(6): 1126-1138.

8. R Development Core Team. (2012). R (Version 2.15). Retrieved from www.r-project.org

9. Brophy VH, Jampsa RL, Clendenning JB, McKinstry LA, Jarvik JP, Furlong CE. Effets of 5' regulatory region polymorphisms on paraoxonase-gene (PON1) expression.
Am J Hum Genet 2001; 68: 1428-1436.

10. Leviev I, James RW. Promoter polymorphisms of human paraoxonase PON1 gene and serum paraoxonase activities and concentrations. Arterioscler Thromb Vasc Biol 2001; 20: 516-521.

11. Mackness B, Turkie W, Mackness M. Paraoxonase 1 (PON1) promoter region polymorphisms, serum PON1 status and coronary heart disease. Arch Med Sci 2013; 9(1): 8-13.

12. Furlong CE. Paraoxonase: an historical perspective. In: The Paraoxonase: Their Role in Disease Development and Xenobiotic Metabolism. Mackness B, Mackness M, Aviram M and Paragh G. (eds.) Springer, Dordrecht, Netherlands: 2008; 3-31.

13. Wheeler JG, Keavney BD, Watkins H, Collins R, Danesh J. Four paraoxonase gene polymorphisms in 11212 cases of coronary heart disease and 12786 controls: meta-analysis of 43 studies. Lancet 2004; 363: 689-695. 